\title{
A Research to Determine The Burnout Level of Elementary School Supervisors Working in GAP Region*
}

\author{
Refik BALAY ${ }^{* *}$
}

\author{
Adnan ENGİN***
}

\begin{abstract}
This study aims to determine the level of burnout feelings of supervisors working in GAP region. The population of the research composed of elementary school supervisors who were serving in the cities of the Southeastern Anatolia Region. Since the research was done on the entire population, no sampling was needed to be applied. The Maslach Burnout Inventory developed by Maslach and Jackson (1981) was used to collect data about the level of burnout experienced by the elementary school supervisors. Results showed that in general the elementary school supervisors experienced a medium level of burnout. The results also show that the elementary school supervisors experience a medium level of burnout in the dimension of 'emotional exhaustion', a low level of burnout in 'depersonalization' and in the dimension of 'personal accomplishment' they experienced a burnout somewhere around the border.
\end{abstract}

Key Words: Burnout, emotional exhaustion, depersonalization, personal accomplishment, elementary school supervisors.

* This study was prepared from Master Thesis which was done under the supervision of Assistant Prof. Dr. Refik BALAY, in Harran University, Institute of Social Sciences.

${ }^{* *}$ Harran University Faculty of Arts and Science Department of Educational Sciences

**** Elementary School Supervisor in National Education Directorate of Şanlıurfa 


\section{SUMMARY}

The purpose of this study is to determine the level of burnout feelings of supervisors working in GAP region. In the study burnout feelings of supervisors are investigated in the subscales of 'emotional exhaustion', 'depersonalization' and 'personal accomplishment'. It also aims to examine whether the burnout level of supervisors differentiates according to their gender, the branch as they were teacher, age, the administrative duties prior to become a supervisor, the number of supervisors they work with and the length of working time in the same city

The population of the research composed of elementary school supervisors who were serving in the GAP region. Of the 244 conducted questionnaires, 199 were returned and 197 ( 82 per cent) of these were used in the analysis. This research is a descriptive survey model. A "Personal Information Form" consisting of 6 questions was used to collect data regarding the personal characteristics of the supervisors and the Maslach Burnout Inventory was used to collect data about the burnout level experienced by the elementary school supervisors. The research instrument were combined into a single form and applied together.

The Maslach Burnout Inventory was developed by Maslach and Jackson (1981), consists of 22 items and measures the burnout in three dimensions. The inventory, which was translated into Turkish by Çam (1992) and Ergin (1992) was tested for validity and reliability. The three dimensions of the inventory are: Emotional Exhaustion-EE consisting of 9 items, Depersonalization-D consisting of 5 items and Personal Accomplishment-PA consisting of 8 items. The statistical analysis of the data gathered by this research was done on a computer environment using the SPSS program. Frequency, percentage distribution, mean, standard deviation, $t$ test, one way Anova, Scheffe and Dunnet $C$ tests were utilized in the analysis.

Results showed that in general the elementary school supervisors experienced a medium level of burnout. They experience a medium level of burnout in the dimension of 'emotional exhaustion', a low level of burnout in 'depersonalization' and in the dimension of 'personal accomplishment' they experienced a burnout somewhere around the border.

Results also revealed that in the dimension of 'emotional exhaustion', female supervisors experienced a higher level of burnout than their male colleagues. Supervisors who were previously a classroom teacher experienced a higher level of burnout than those who were specialized in a specific teaching branch. While the burnout level of elementary school supervisors decreased with age in the 'emotional exhaustion' and 'depersonalization', their views related to 'personal accomplishment' 
increased with age. The burnout level of supervisors was significantly higher for those who had not been in an administrative position in their professional life prior to become a supervisor in 'emotional exhaustion' and 'depersonalization' dimensions. The opinions of supervisors related to 'personal accomplishment' were found to be higher for those who had an administrative position in their professional life than those who did not have any administrative position. Supervisors who work in groups of 41 or above, experience a higher level of burnout in 'emotional exhaustion' than those who work in groups of 21-30 and those who worked in the same city for approximately 4-6 years, experienced a higher level of 'emotional exhaustion' than those who had been there over 10 years. 


\section{GAP Bölgesinde Görev Yapan İlköğretim Müfettişlerinin Tükenmişlik Düzeyi Üzerine Bir Araştırma*}

Refik BALAY**
Adnan ENGÍN ${ }^{* * *}$

ÖZ. Bu araştırma, GAP Bölgesinde görev yapan ilköğretim müfettişlerinin tükenmişlik duygularının hangi düzeyde olduğunu ortaya koymayı amaçlamaktadır. Araştırmanın evrenini, Güneydoğu Anadolu Bölgesindeki illerde görev yapan ilköğretim müfettişleri oluşturmuştur. Araştırma, evrenin tümü üzerinde yapıldığından, örneklem alma yoluna gidilmemiştir. Araştırmada, veri toplamak amacıyla Maslach ve Jackson (1981) tarafından geliştirilen 'Maslach Tükenmişlik Ölçeği' (Maslach Burnout Inventory) kullanılmıştır. Araştırma sonucunda, ilköğretim müfettişlerinin genel olarak tükenmişlik duygusunu orta düzeyde yaşadıkları bulunmuştur. Bulgular, ayrıca ilköğretim müfettişlerinin tükenmişlik duygusunu, 'duygusal tükenme' boyutunda orta düzeyde, 'duyarsızlaşma' boyutunda düşük düzeyde, 'kişisel başarı' boyutunda ise sınırda yaşadıklarını göstermiştir.

Anahtar Sözcükler: Tükenmişlik, duygusal tükenme, duyarsızlaşma, kişisel başarı, ilköğretim müfettişleri.

\footnotetext{
* Harran Üniversitesi Sosyal Bilimler Enstitüsü'nde Yrd. Doç. Dr. Refik BALAY danışmanlığında yapılmış olan Yüksek lisans tezinin bir kısmından yararlanılarak hazırlanmıștır.

${ }_{* * *}^{*}$ Harran Üniversitesi Fen Edebiyat Fakültesi Eğitim Bilimleri Bölümü

**** Şanlıurfa İl Milli Eğitim Müdürlüğü İlköğretim Müfettişi
} 


\section{GİRIS}

1970'li yılların sonu ve 1980'li yılların başında ortaya çıkan tükenmişlik kavramı, ilk olarak 1974 yılında örgütsel stres üzerinde uzun yıllar çalışmış olan H. Freudenberger tarafından ortaya atılmışıı. Freudenberger, insanlarla etkileşim içerisinde olan kişilerde gördüğü bu duruma tükenmişlik adını koymuştur (Izgar, 2001).

Maslach ise tükenmişlik konusunda otorite olarak kabul edilmesini sağlayan birçok araştırma yapmıştır. Tükenmişlik, daha çok zamanlarının büyük bir bölümünü toplumdaki diğer insanlarla geçirmek zorunda kalan kamu hizmeti çalışanlarında ortaya çıkmaktadır. Bu çalışanlar kronik stres ve tükenmişlik riskiyle karşı karşıyadır. Tükenmişlik, insanlara yardım hizmeti sunan bireyler arasında ortaya çıkan ve duygusal tükenme, duyarsızlaşma ve kişisel başarının azalmasını içeren bir sendrom olarak tanımlanmıştır. (Maslach ve Jackson, 1981).

Duygusal tükenme (emotional exhaustion), çalışanların halsizlik ve aşırı yorgunluk nedeniyle kendilerini duygusal yönden yıpranmış hissetmeleri olarak ifade edilirken, duyarsızlaşma (depersonalization), özellikle, hizmet verilen alanlarda bireylere karşı olumsuz tutum ve tepkiler ortaya konulmas1, çoğunlukla sinirlilik ve işe ilişkin idealizm kaybı olarak tanımlanmaktadır. Kişisel başarı (personal accomplishment) ise, depresyon, düşük moral, kişiler arası ilişkilerde geri çekilme, üretkenliğin azalması, başarısızlık duygusu ve zayıf özgüven ile kişinin kendisine ve kişisel başarısına ilişkin olumsuz tepkilerini içerir (Maslach ve Jackson, 1981).

Duygusal tükenme boyutu fiziksel ve duygusal yorgunluk durumlarını ifade eder ve tükenmişliğin merkezinde yer alan en önemli boyuttur. Tükenmişliğin üç boyutlu yapısı pek çok araştırma ile desteklenmekle birlikte, tükenmişliğin temelinde duygusal tükenme boyutunun bulunduğu, duyarsızlaşma ve kişisel başarı boyutlarının buna eşlik ettiği ileri sürülmektedir (Çokluk, 2003).

İş ortamındaki stres, günlük iş yükü ve taleplerinin bir parçası olarak ortaya çıkmaktadır. $\mathrm{Bu}$ iş yükü ve beklentileri altında birey, yardım alamadığında veya desteklenmediğinde uzun süreli stres yaşamakta ve bu durum sonuçta tükenmişliğe dönüşebilmektedir. Tükenmişlik, örgüt ve birey açısından ağır ve ciddi sonuçları beraberinde getireceği için üzerinde çalışılması ve önlenmesi gereken bir durum olarak kabul edilmektedir.

\section{Problem}

Sözlük tanımında tükenmişlik, enerji, güç ve kaynaklar üzerinde aşırı taleplerden dolayı, başarısız olmak, yavaş yavaş yıpranmak ya da yorulmaktır. Öznel bir olgu olarak ele alındığında tükenmişlik, duygusal taleplerin yoğun olduğu ortamlarda uzun süre çalışan, fiziksel olarak 
yıpranan, çaresizlik, ümitsizlik ve hayal kırıklığı ile birlikte olumsuz benlik tasarımı geliştiren, işyerinde çalışanlara ve yaşama karşı olumsuz tutumlar besleyen kişilerde görülen bir durumdur (Çokluk, 2003).

Baltaş ve Baltaş’a (1997) göre bireyin işini sevmesi, sağlıklı bir yaşam sürmesi için zorunludur. Ancak aşırı iş yükü, işinden hoşlanan birey için bile, doğrudan ağır bir strestir. Çeşitli nedenlerle yoğun iş yükü altında yaşayan kişiler "tükenme" durumuyla karşı karşıya kalmaktadırlar. Maslach ve Jackson (1981: 106) tarafından yapılan araştırmada çalışanların ilgilenmeleri gereken insan sayısı arttıkça tükenmişlik düzeylerinin de arttığı gözlemlenmiştir. $\mathrm{Bu}$ kişilerde tükenmişliğin boyutlarından duygusal tükenme ve duyarsızlaşmanın arttığı, kişisel başarının azaldığı ortaya çıkmıştır

İşgörenlerde strese neden olan her etken, onların güdülenmelerini önemli ölçüde etkilemektedir. Stresin belli bir miktarda varlığı işgörenleri güdüleyerek performanslarını arttırırken, stres miktarının artması tam tersi bir etki yapmaktadır. Uygun olmayan çalışma koşulları, huzursuzluk, ast-üst ve iş arkadaşlarıyla anlaşmazlık gibi işgörenin performansını olumsuz etkileyen bir çok stres kaynağı mevcuttur (Sağlam, 2003). Maslach ve Jackson (1981), stres kaynaklarının tükenmişlikle bağlantılı olduğunu bildirmektedirler. Aynı araştırmada tükenmişliğin boyutlarında cinsiyete göre fark olduğu bulunmuştur. Kadınlar erkeklere göre daha fazla duygusal tükenme yaşamaktadırlar. Yaş değişkeni açısından bulgulara bakıldığında, genç yaştakilerin ileri yaştakilere göre daha fazla duyarsızlaşma ve duygusal tükenme yaşadıkları ortaya çıkmıştır. Bekar veya boşanmış olanların duygusal tükenme düzeylerinin evli olanlara göre daha yüksek olduğu bulunmuştur. Yüksek okulu bitirenlerin duygusal tükenme ve kişisel başarı boyutlarında tükenmişlik düzeyleri, yüksek okulu bitirmemiş olanlara göre daha yüksek olarak ortaya çıkmıştır.

Randall (1993), öğretmenlerde tükenmişlik, depresyon belirtileri ve başa çıkma stratejilerini incelediği araştırmasında kent merkezinde çalışan öğretmenlerin duygusal tükenme ve kişisel başarı boyutlarında daha fazla tükendiklerini bulmuş, kırsal kesimde çalışan öğretmenlere oranla merkezde çalışan öğretmenlerin daha fazla depresyon belirtileri gösterdiklerini tespit etmiştir. Shapiro (1987), öğretmen tükenmişliğinin kişisel ve çevresel değişkenlerle ilişkisini incelediği araştırmasında öğretmenlerin, tükenmişliği belirli bir düzeyde yaşadıklarını bulmuş, bayanlarla erkekler arasında, özel eğitim öğretmenleriyle diğer öğretmenler arasındaki tükenmişlik düzeyinde anlamalı farklılık olduğunu saptamış, yaş, mesleki kıdem, öğretim görevi ile tükenmişlik arasında anlamlı bir ilişki olmadığını bulgulamıştır. Teague (1992), hemşirelerde tükenmişlik ve tükenmişlikle başa çıkma yöntemleri arasındaki ilişkiyi incelediği araştırmasında belirli demografik değişkenler ve öncelikli çalışma birimleri istatistiksel olarak kontrol edildiğinde, 
duygusal anlamda daha fazla çaba gösteren hemşirelerde daha yüksek oranlarda tükenmişlik görüldüğünü gözlemiştir. Manlove (1992) ise, eğitimcilerin kalitesini belirleyen faktörlerden birinin tükenmişlikleri olduğuna dikkat çektiği araştırmasında mesleğe bağlılık, eğitim düzeyi ve deneyim gibi kişisel değişkenlerin tükenmişliğe önemli etkilerde bulunduğunu ortaya koymuş, ayrıca, mesleki tatmin ve sosyal destek değişkenlerinin tükenmişliği çok az etkilediğini belirlemiştir.

Garcia (2004), öğretmenlerin tükenmişliklerine etki eden kişisel ve çevresel faktörleri incelediği araştırmasında dışa dönük öğretmenlerin daha yüksek tükenmişlik duygusu yaşadıklarını, sinirli yapıya sahip olanların daha olumsuz duygular, ruhsal dengesizlikler ve sert tepkiler gösterdiklerini bulmuştur. Aynı araştırma bulgularına göre psikolojik sorunların fazlalığı, yönetimle olan iletişimin yetersizliği, terfi olanaklarının azlığı ve mesleki prestijin düşük olmasının, duygusal tükenmeye etki eden değişkenlerin başında geldiği, özel okullarda çalışan ve öğrencilerle iyi ilişkiler kuran hoşgörülü öğretmenlerin kişisel başarılarının da daha yüksek olduğu ortaya çıkmıştır.

Türkiye'de çalışanların tükenmişliği üzerinde yapılan araştırmalara bakıldığında, bu alandaki çalışmaların özellikle sağlık çalışanları ve öğretmenler üzerinde yapıldığı görülmektedir. Ergin (1992) Üstün (1995) ve Demir (1995) tükenmişliğin doktorlar ve hemşireler arasında, Girgin (1995) Torun (1995) ve Tümkaya (1996) ise yönetici ve öğretmenler arasında daha fazla görüldüğünü, bunun, birey açısından iş değiştirme, işten ayrılma ve erken emeklilik gibi sonuçlara neden olduğunu, toplumsal açıdan da nitelikli işgörenlerin kaybına, hizmet kalitesinde düşüşe ve ekonomik kayıplara yol açtığını belirtmişlerdir.

Ergin (1992), doktor ve hemşirelerin tükenmişliği ile Maslach Ölçeği'nin uyarlanması üzerinde yaptığı araştırmada kadınların erkeklerden duygusal olarak daha çok tükendiklerini, başarı boyutunda erkeklerin bireysel başarı duygusunun kadınlardan daha yüksek olduğunu bulmuştur. Aynı araştırma bulgularına göre ayrıca, çalışma süresi arttıkça tükenmişliğin azaldığ 1 , duyarsızlaşma şeklindeki tükenmişliğin bekar hemşirelerde evli olanlardan daha yüksek olduğu; duyarsızlaşma ve duygusal tükenme boyutlarında bekar doktorların evli olanlardan daha fazla tükendikleri ortaya çıkmıştır.

Girgin (1995), ilkokul öğretmenleri üzerinde yaptığı araştırmada meslekte tükenmişliğin gelişimini etkileyen değişkenleri incelemeye çalışmıştır. Sonuçlara göre, mesleği isteyerek seçip seçmeme, mesleği sürdürme nedeni, meslektaşlardan destek, üstlerden takdir görme durumu, mesleğin toplumda hak ettiği yeri bulup bulmadığı kanıs1 ve eğitim sisteminden memnun olup olmama durumu, duygusal tükenme boyutunu; 
cinsiyet, çalışma y1lı, mesleğin toplumda hak ettiği yeri bulup bulmadığı kanıs1, eğitim sisteminden memnuniyet durumu ve çalışılan sosyo-ekonomik düzeyin, duyarsızlaşma boyutunu; çalışma yıl1, okuldaki konum, mesleği sürdürme nedeni, üstlerden takdir görme durumu ve çalış1lan sosyoekonomik düzey değişkenlerinin ise tükenmişliğin kişisel başarı boyutunu etkileyen değişkenler olduğu belirlenmiştir.

Baysal (1995), lise ve dengi okul öğretmenleri üzerinde yaptı̆̆ 1 araştırmada, meslekte tükenmişliğe etki eden değişkenleri saptamaya çalışmıştır. MTE kullanılarak yapılan çalışma sonunda önemli değişkenler olarak mesleğin gereklerini yerine getirmedeki verimlilik, geleceğe ilişkin düşünceler, meslektaş desteği ve aile desteğinin tükenmişliği etkileyen değişkenler olduğunu bulmuştur. Torun (1995), öğretmenler, satış elemanları ve trafik polisleri gibi farklı meslek gruplarından insanlar üzerinde yaptığı araştırmada tükenmişlik, aile yapısı ve sosyal destek ilişkisini incelemiştir. Araştırma sonunda tükenmişliğin aile yapısı ve sosyal destek ile, aile yapısı ve sosyal desteğin de birbirleriyle ilişkili olduğunu bulmuştur.

Sucuoğlu ve Kuloğlu-Aksaz (1996) engelli çocuklarla çalışan öğretmenlerin tükenmişliğini incelemişlerdir. Ö̈zel eğitim ve ilkokul öğretmenleri üzerinde yaptıkları araştırma sonunda iki öğretmen gurubunun toplam tükenmiş̧lik puanları arasında anlamlı fark olmadığını, ancak ilkokul öğretmenlerinin kişisel başarı puanlarının özel eğitim öğretmenlerinden daha fazla olduğunu bulmuşlardır. Ayrıca özel eğitim öğretmenlerinin toplam tükenmişlik ve alt ölçek puanlarının, çalışan çocuğun özür türü ve öğretmeninin eğitimi ile ilişkili olduğu bulunmuştur. Tümkaya (1996), öğretmenlerde tükenmişlik, psikolojik belirtiler ve başa çıkma davranışlarını ele aldığı araştırmasında, mesleğe ve çalışma koşullarına ilişkin görev algısı, iş değiştirme isteği, işte yükselme olanağ 1 ve çalışılan okulun sosyoekonomk düzeyinin tükenmişlikle ilişkili olduğu saptanmıştır. Baltaş ve Baltaş (1997) ise tükenmişlik eğilimi yüksek olan kişilere özel dikkat çekmektedirler. Bu yazarlara göre tükenmişlik, çoğunlukla çok başarılı olmak için yoğun biçimde çalışan, her çalışmada kendisinden beklenenin ötesinde çaba ortaya koyan ve iş yapmada genellikle sınırları zorlayan kişilerde görülmektedir.

Akçamete, Kaner ve Sucuoğlu (2001) öğretmenlerde tükenmişlik, iş doyumu ve kişilik üzerinde yaptıkları çalışmada, tükenmişliğin, insanlara hizmet veren mesleklerde çalışanların sıklıkla yaşadıkları fiziksel, duygusal ve zihinsel bir sendrom olduğunu ifade etmişlerdir. Yazarlara göre, bu tür sendromları yaşayan bireyler, çalıştıkları yerlerde yoğun duygusal beklentilere girdiklerinde, zamanla hizmet verdikleri kişilere olan ilgi ve duyarlıklarını yitirmekte, kendilerine ve hizmet sundukları kişilere karşı olumsuz duygular göstermektedirler. $\mathrm{Bu}$ olumsuz duygular bireylerin 
verimini düşürmekte, işten elde ettikleri doyumu azaltmakta ve ortaya koydukları hizmetin kalitesini yok etmektedir.

Çimen (2007) tarafindan ilköğretim öğretmenlerinin tükenmişlik yaşantıları ve yeterlik algıları üzerinde yapılan araştırmada, yöneticiler, öğrenciler ve çalışma arkadaşlarından alınan desteğin öğretmenin tükenmişliğinde koruyucu bir faktör olduğu, yönetici ve çalışma arkadaşlarından alınan desteğin düşük tükenmişlik düzeyi ile ilişkili bulunduğu ileri sürülmüştür. Aynı araştırmaya göre ilgili, çalışkan ve başarılı öğrencilerin tükenmişliği önleyici etki yarattığ1, yöneticiler tarafından öğretmenlerin çalışmalarının ödüllendirildiği ve öğretmenlerin, kendilerini güçlü hissettikleri bir çalışma ortamının tükenmişliğin klasik belirtilerini ortadan kaldırdığı ifade edilmiştir.

\section{Yönetici ve Müfettişlerin Tükenmişliği}

Diğer yandan gerek yurt dışında gerekse Türkiye'de sınırlı da olsa yönetici ve müfettişlerin tükenmişliği üzerinde bazı araştırmaların yapıldığ 1 görülmektedir. Örneğin, Daly (1992), resmi okul yöneticilerinin tükenmişlik düzeylerini incelediği araştırmasında yöneticilerin tükenmişlik puanlarında daha önce yapılmış araştırmalara göre artış olduğu, çalışılan okul türü ve büyüklüğü ile tükenmişlik arasında yüksek bir ilişki olmadığı sonucuna varmıştır. Yazara göre yöneticilerin, başarısızlık, suçluluk, kuşkulanma ve tahammülsüzlük gibi tükenmişlik belirtilerini yüksek düzeyde yaşamalarının nedeni, son yıllarda eğitim kurumlarında artan baskılar, okul merkezli yönetimin yöneticiye yüklediği ek sorumluluklar ve otorite boşluğunun ortaya çıkmış olmasıdır.

Walter ve Gates (1998) ise kişisel, mesleki ve örgütsel özelliklerin eğitim müfettişleri ve yöneticilerin tükenmişliği üzerindeki etkilerini ele aldıkları araştırmalarında işinden memnun olanlarda tükenmenin, özellikle duygusal tükenme boyutunda düşük olduğunu, ayrıca işten elde edilen doyum ile görev kaynaklı stres arasında ters bir ilişki olduğunu bulmuşlardır. Aynı araştırma bulgularına göre, duyarsızlaşma ile düşük kişisel başarı duygusunun en çok rol çatışmasından etkilendiği, rekabetçi yaklaşımı benimseyen yöneticilerin, daha yüksek stres yaşadıkları, iş doyumu için denetleyicilerden gelen sosyal desteğin, iş arkadaşlarından ve aileden gelen sosyal destekten daha önemli olduğu ortaya çıkmıştır.

Örmen (1993) yöneticilerin tükenmişlik duygusunu incelediği araştırmasında yönetici grubu olarak banka yöneticileri üzerinde çalışmıştır. Sonuçlara göre tükenmişliğin hem kişisel hem de örgütsel bir bütün olarak ortaya çıktığ 1 , deneyimi az, aile ilişkileri zayıf ve amaçları belirsiz olan bireylerde tükenmişlik yaşama ihtimalinin daha fazla olduğu, tükenmişlik yaşayan bireylerde hastalık, yorgunluk ve depresyon gibi psikolojik rahatsızlıkların baş gösterdiği, yaşanan çatışmalar, aşırı iş yükü ve kötü 
yönetimin tükenmişliğe etki eden faktörler olduğu, duygusal tükenmenin yöneticiler için en büyük sendrom oluşturduğu, ilk yöneticilik basamaklarında bulunanlarda tükenmişlik puanlarının yüksek, buna karşın, üst düzey yöneticilerde söz konusu tükenmişlik puanlarının önemli oranda düştüğü, tükenmişlik sorunlarının kişi üzerindeki etkilerinin ise kişiden kişiye önemli farkl1lıklar gösterdiği ortaya çıkmıştır.

Izgar (2001) tarafindan yapılan araştırmada okul yöneticilerinin tükenmişlik düzeyi ile branşları arasında duygusal tükenme boyutunda anlamlı ilişki bulunmuş, meslek dersi branşından olan yöneticilerin duygusal tükenmişlik düzeylerinin diğerlerinden daha yüksek olduğu görülmüştür. Aydın'ın (2002) ilköğretim okulu yöneticilerinin bireysel tükenmişlik düzeylerinin belirlenmesi amacıyla yaptığı araştırmada ise en yüksek duygusal tükenme puanlarının 41-50 arası öğretmenle çalışan yöneticilerde ortaya çıtı̆̆ğ görülmüştür.

Babaoğlan (2006), ilköğretim okulu yöneticilerinin tükenmişliğini incelediği çalışmasında, yöneticilerin az düzeyde tükenmişlik yaşadıklarını, en fazla tükenmişliği duygusal tükenme boyutunda, en az tükenmişliği ise duyarsızlaşma boyutunda yaşadıklarını ortaya koymuştur. Ayrıca bulgulara göre, toplam tükenmişlikte kadın yöneticilerin erkek olanlardan; duygusal tükenme, kişisel başarısızlık, ve toplam tükenmişlik boyutlarında bekar yöneticilerin evli olanlardan; duyarsızlaşma boyutunda yaş grubu ve mesleki kıdemi yüksek yöneticilerin daha düşük olanlardan; duygusal tükenme ve toplam tükenmişlik boyutlarında da yöneticilik kıdemi az olanların, yöneticilik kıdemi fazla olanlardan daha fazla tükenmişlik yaşadığı gözlenmiştir. Altay (2007) ise okul yöneticilerinin mesleki tükenmişlik düzeyleri ile çok boyutlu algılanan sosyal destek düzeyleri arasındaki ilişkiyi ele aldığı araştırmasında mesleki tükenmişlik ile çok boyutlu algılanan sosyal destek arasında negatif bir ilişki olduğunu; buna göre sosyal destek düzeyi artarken tükenmişlik düzeyinin azaldığı, okul yöneticilerinin tükenmişliği ile algılanan sosyal destek düzeylerinde yaş ve cinsiyet değişkenlerine göre anlamlı bir farklılık oluşmadığı saptanmıştır.

Teftiş (denetim), kurumun amacina ulaşması için çalışan personele yardım etme, yol gösterme, gelişimine katkıda bulunma gibi hizmetlerin yanında, personelin hizmetlerinin değerlendirilmesini de kapsamaktadır. Ayrıca yasa dışı eylemlerin soruşturulmasını da müfettişler yapmaktadır. Birbirine zıt düşen görevler aynı kişiye verilmiş olmaktadır (Taymaz, 1997). İlköğretim müfettişleri, bir okulda soruşturma yapmak üzere sorgu yargıçlığ 1 rolünü oynayarak yönetici ve öğretmenlere ceza verilmesini teklif etmekte, daha sonra aynı okulda rehberlik veya liderlik rolünü sergilemeye çalışmaktadırlar. $\mathrm{Bu}$ durum yönetici ve öğretmenlerin kabul alanını daraltmakta, etkililiği azaltmakta, rol çatışmasına neden olmakta ve öğretmen-müfettiş ilişkilerinde olumsuzluğa yol açmaktadır. 
Görev alanları incelendiğinde ilköğretim müfettişlerinin oldukça geniş ve yoğun bir iş yüküne sahip oldukları anlaşılmaktadır. Bir ilde ortalama 70 öğretmene bir müfettiş görevlendirilmesi öngörülmesine rağmen, yapılan araştırmalar bir müfettişe ortalama 150 öğretmenin düştüğünü göstermektedir (Aydın, 1993: 168). Bu sayının özellikle GAP bölgesindeki illerde daha fazla olduğu söylenebilir. Yukarıda sayılan etkenler değerlendirildiğinde, ilköğretim müfettişlerinin görev alanlarının fazlalığından ve sayılarının azlığından doğan aşırı iş yükünün görevlerini yaparken zorluklar yarattı açıtır. GAP bölgesinde çalışan ilköğretim müfettişlerinin diğer gelişmiş bölgelerde, daha iyi koşullarda görev yapan müfettişlere göre sözkonusu bu güçlükleri daha yoğun bir şekilde yaşadıkları tahmin edilebilir.

Diğer yandan, Milli Eğitim Bakanlığı'nda bakanlık müfettişliği ve ilköğretim müfettişliği olarak iki ayrı denetim biriminin olması nedeniyle örgütsel yapılanmadan kaynaklanan sorunlar, ilköğretim müfettişlerinin hiyerarşideki ve protokoldeki yerlerinin belirlenmemiş olması, yönetimin sadece karar süreci olarak anlaşılması ve diğer süreçlerin önemsenmemesi, üst ve astlar arasında mesleksel ve kişisel ilişsilerin karıştırılması, teftiş edilen öğretmen ve yöneticilerin müfettişle işbirliği yapmaktan kaçınmaları, sorunlarını müfettişe samimi olarak açmamaları, teftişe soğuk bakmaları, teftiş sonunda verilen raporların yöneticiler tarafindan gereği şekilde değerlendirilmemesi, teftişte politik baskıların olması, özellikle iktidar değişikliklerinde bu tür sıkıntıların artması, kurumdaki diğer birimlerin teftiş birimiyle işbirliği yapmaktan kaçınmaları, bazen usulsüz ihbar ve şikayetlerin soruşturmasının istenmesi, müfettişlere verilen soruşturmaların fazla ve bazılarının gereksiz olması gibi nedenlerin, müfettişlerin görevlerinde güçlükler yarattığı ileri sürülmüştür (Taymaz, 1997; Kayıkçı, 2005).

Yukarıda sayılan nedenlerin etkisiyle ilköğretim müfettişlerinin görevlerini yerine getirirken stres yaşadıkları ve bu sorunların tükenmişliğe yol açtığ 1 düşünülmektedir. $\mathrm{Bu}$ açıdan bakıldığında eğitim sistemimizi geliştirmede sadece öğretmen ve yönetici tükenmişliği üzerinde çalışmanın yeterli olmayacağı; öğretmenler ve yöneticilerle sık1 iletişim içinde olan müfettişlerin tükenmişliğinin de ayrıntılı biçimde incelenmesi, nedenlerinin belirlenmesi ve ortadan kaldırılmasına yönelik çalışmaların yapılması önem arzetmektedir. Tükenmişlik, diğerlerine yardım hizmeti sunan meslek elemanları gibi ilköğretim müfettişleri için de istenmeyen bir durum olarak ortaya çıkmaktadır; çünkü bu süreci yaşayan ilköğretim müfettişinin, görevini yerine getirmede sorunlar yaşayacağı ve etkililiğinin düşeceği düşünülmektedir. Temel görevleri öğretmenlere rehberlik yaparak eğitim sürecini geliştirmek olan ilköğretim müfettişlerinde stres düzeyinin yüksek 
olduğu ve tükenmişliğin farklı düzeylerde yaşandığ 1 söylenebilir. Bu durum eğitim sisteminde niteliği ve verimliliği düşürecek sorunlardandır.

Çeşitli mesleklerde çalışanların tükenmişlik duygularının araştırılması önemli bir konudur. Bugüne kadar ilköğretim müfettişleri üzerinde sınırlı sayıda araştırma yapılırken, GAP bölgesinde görev yapan ilköğretim müfettişlerinin tükenmişlik düzeyi ile ilgili herhangi bir araştırma yapılmadığı anlaşılmaktadır. Oysa bu bölgedeki müfettişlerin sayıca yetersiz oluşu, iş yüklerinin fazlalığı, tayin güçlükleri, bölgenin eğitim açısından Türkiye ortalamasının çok altında bulunması ve düşük sosyo-ekonomik yapı nedeniyle diğer bölgelerde görev yapan ilköğretim müfettişlerinden daha fazla sorun yaşadıkları tahmin edildiğinden, bu bölgede görev yapan ilköğretim müfettişlerinin tükenmişlik duygularının araştırılması gereği ortaya çıkmıştır. Böylece ilköğretim müfettişlerinin denetim etkinliklerinde daha verimli olmaları için alınabilecek önlemler ortaya konularak, yeniden yapılanma süreci içerisindeki Milli Eğitim Bakanlığı denetim sistemine de katkıda bulunacağı umulmaktadır.

\section{Amaç}

$\mathrm{Bu}$ araştırmanın amac1, GAP bölgesinde görev yapan ilköğretim müfettişlerinin tükenmişlik duygularını çeşitli değişkenler açısından incelemektir.

Araştırmanın amaçlarını gerçekleştirmek üzere aşağıdaki sorulara yanıt aranmıştır:

1) Araştırmaya katılan ilköğretim müfettişlerinin tükenmişlik duyguları ne düzeydedir?

2) Araştırmaya katılan ilköğretim müfettişlerinin tükenmişlik duyguları, onların cinsiyetlerine, öğretmenlikteki branşlarına, yaşlarına, müfettişlikten önceki çalışma hayatında yöneticilik görevinde bulunup bulunmamalarına, birlikte çalışılan müfettiş sayısına ve aynı ilde görev yapma süresine göre farklılaşmakta mıdır?

\section{YÖNTEM}

\section{Araştırmanın Modeli}

İlköğretim müfettişlerinin tükenmişlik duyguları ile tükenmişliklerine etki eden değişkenlerin bir incelemesine yönelik bu çalışma, betimsel tekil tarama modelinde bir araştırmadır. Bilindiği gibi bu yolla elde edilen araştırma sonuçları güncel problemlerin çözümünde büyük yararlar sağlayabilmektedir. Çünkü mevcut durumlar, koşullar ve özellikler aynen ortaya konulmaktadır (Kaptan, 1998). 


\section{Araștırmanın Evreni}

Araştırmanın evrenini, 2004-2005 eğitim-öğretim yılında Güneydoğu Anadolu Bölgesinde Adıyaman, Batman, Diyarbakır, Gaziantep, Kilis, Mardin, Siirt, Şanlıurfa ve Şırnak illerinde görev yapan 244 Milli Eğitim Bakanlığ 1 ilköğretim müfettişleri oluşturmaktadır. Araştırma, evrenin tümü üzerinde yapıldığından, örneklem alma yoluna gidilmemiştir.

\section{Veri Toplama Aracı}

Araştırmada kullanılan ölçme aracı Şanlıurfa ilinde araştırmacılar tarafından bizzat uygulanmış, diğer illerdeki meslektaşlara ise posta yoluyla gönderilmiş, uygulama sonunda yine posta yoluyla araştırmacılara geri yollanmıştır. 244 anketin 199'u geri dönmüştür. Uygulama sonunda veri toplama aracında yapılan açıklayıcı yönergeye uygun olarak doldurulmadığ 1 anlaşılan 2 adet anket formu değerlendirme dışı bırakılarak, toplam 197 ilköğretim müfettişinin verileri üzerinde istatistiksel işlemler yapılmıştır.

Araştırmada ilköğretim müfettişlerinin kișisel nitelikleri ve mesleklerine ilişkin bilgiler için araştırmacı tarafindan hazırlanan "Kişisel Bilgi Formu" kullanılmıştır. Bilgi Formunda cinsiyet, öğretmenlikteki branş, yaş, müfettişlikten önceki çalışma hayatında yöneticilik yapıp yapmadığı, birlikte çalışılan müfettiş sayısı ve aynı ilde görev yapma süresi gibi kişisel ve mesleki değişkenlere göre ilköğretim müfettişlerinin durumlarını belirlemek amaciyla toplam 6 madde yer almaktadır.

İlköğretim müfettişlerinin tükenmişlik duyguları hakkında veri toplamak amaciyla Maslach Tükenmişlik Envanteri (Maslach Burnout Inventory) kullanılmıştır. Maslach Tükenmişlik Envanteri (MTE), Maslach ve Jackson (1981) tarafindan geliştirilmiş olup, toplam 22 maddeden oluşmaktadır. Envanterdeki maddeler tükenmişlik sendromunun varsayılan boyutlarını ölçmek için oluşturulmuştur. $\mathrm{Bu}$ boyutlardan "Duygusal Tükenme- DT" (Emotional Exhaustion -EE), 9 maddeden, "DuyarsızlaşmaD" (Depersonalization-DP) ölçeği 5 maddeden, "Kişisel Başar1-KB" (Personal Accomplishment-PA) ölçeği ise 8 maddeden oluşmaktadır. MTE'nin Cronbach Alpha güvenilirlik katsayıları sırasıyla duygusal tükenme boyutu için 0.89 , duyarsızlaşma boyutu için 0.77 ve kişisel başarı boyutu için 0.74 olarak bulunmuştur.

Envanterin ülkemiz koşullarına uyarlama çalışmaları Çam (1992), Ergin (1992) ve Girgin (1995) tarafından yapılmıştır. Çam (1992) tarafindan yapılan araştırmada Cronbach Alpha katsayıları duygusal tükenme boyutu için, 0.89 , duyarsızlaşma boyutu için, 0.71 ve kişisel başarı boyutu için, 0.72 olarak bulunmuştur. Ergin (1992), Maslach Tükenmişlik Envateri'nin yedi basamaklı cevap seçeneklerini 5'li Likert derecelendirme ölçeğine indirerek uygulamıştır. Doktor ve hemşireler üzerinde uyguladığ 1 envanterin 
güvenirlik hesaplamaları sonucunda elde edilen Cronbach Alpha katsayıları duygusal tükenme boyutunda 0.83 , duyarsızlaşma boyutunda 0.65 , kişisel başarı boyutunda ise 0.72 olarak bulunmuş; daha sonra test -tekrar test yöntemiyle 2-4 hafta sonra elde edilen katsayılar, duygusal tükenme boyutu için 0.83 , duyarsızlaşma boyutu için 0.72 , ve kişisel başarı boyutu için 0.67 olarak hesaplanmıştır. Girgin de (1995), MTE’nin öğretmenlere uygulanması için yaptığ 1 çalışmada ölçeğin güvenirliğini test - tekrar test yöntemiyle sınamış, elde edilen Cronbach Alpha katsayıları duygusal tükenme boyutu için 0.86 , duyarsızlaşma boyutu için 0.68 , ve kişisel başarı boyutu için 0.83 olarak hesaplanmıştır.

MTE'ni oluşturan soru maddelerine 0-4 arasında değişen rakamlarla verilen cevaplar, her boyut için ayrı ayrı belirlenmektedir. Buna göre, duygusal tükenme ve duyarsızlaşma boyutlarında; hiçbir zaman $=0$, çok nadir $=1$, bazen $=2$, çoğu zaman $=3$, her zaman $=4$ şeklinde puanlanırken, kişisel başarı boyutunda; hiçbir zaman $=4$, çok nadir $=3$, bazen $=2$, çoğu zaman $=1$, her zaman $=0$ şeklinde puanlanmaktadır. Aşağıda MTE'nin grafiksel anlatımı ve puanlaması yer almaktadır. Yapılan hesaplamalara göre Envanterin birbirinden bağımsız üç kesme noktası bulunmaktadır. Grafikte tükenmişlik düzeyini belirlerken, dağılımın ilk üçte birlik kesmede yer alan puanlar (0-1.33 arası) düşük tükenmişlik düzeyini, ikinci üçte birlik kesmede yer alan puanlar (1.33-2.66 arası) orta tükenmişlik düzeyini, son üçte birlik kesmede yer alan puanlar (2.66-4 aras1) ise yüksek tükenmişlik düzeyini ifade eder.

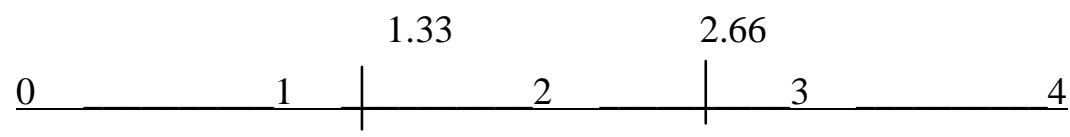

düşük tükenmişlik düzeyi orta tükenmişlik düzeyi yüksek tükenmişlik düzeyi

Grafik 1. Düşük, orta ve yüksek tükenmişlik Düzeyi (Akt: Örmen, 1993)

\section{Verilerin Analizi}

Verilerin analizinde, $\mathrm{t}$ testi ve tek yönlü varyans analizi, Scheffe ve Dunnett C testlerinden yararlanılmıştır. Verilerin çözümlenmesinde anlamlılık düzeyi 0.05 olarak alınmıştır.

\section{BULGULAR}

\section{İlköğretim Müfettişlerinin Kişisel Bilgilerine İlişkin Bulgular}

Kişisel bilgi formuyla elde edilen bilgiler dikkate alınarak ilköğretim müfettişlerinin cinsiyet, öğretmenlikteki branş, yaş, müfettişlikten önceki çalışma hayatında yöneticilik görevinde bulunup bulunmama, birlikte 
çalışılan müfettiş sayısı ve aynı ilde görev yapma süresine ilişkin frekans ve yüzde değerleri Tablo 1'de verilmiştir.

Tablo 1. İlköğretim Müfettişlerinin Kişisel Bilgilerine İlişkin Frekans ve Yüzde Değerleri

\begin{tabular}{|c|c|c|c|}
\hline Değișkenler & Gruplar & Frekans & Yüzde \\
\hline \multirow[t]{2}{*}{ Cinsiyet } & Kadin & 14 & 7.1 \\
\hline & Erkek & 183 & 92.9 \\
\hline \multirow[t]{2}{*}{ Öğretmenlikteki branş } & Sınıf Öğretmeni & 167 & 84.8 \\
\hline & Alan Öğretmeni & 30 & 15.2 \\
\hline \multirow[t]{3}{*}{ Yaş } & $31-40$ & 110 & 55.8 \\
\hline & $41-50$ & 65 & 33.0 \\
\hline & 51 ve üstü & 22 & 11.2 \\
\hline \multirow{4}{*}{$\begin{array}{l}\text { Müfettişlikten önceki } \\
\text { çalışma hayatında } \\
\text { yöneticilik görevinde } \\
\text { bulunup bulunmama }\end{array}$} & Yöneticilik Yapmadım & 87 & 44.2 \\
\hline & $\begin{array}{l}\text { Okulda Müdür } \\
\text { Yardımcılığı }\end{array}$ & 23 & 11.7 \\
\hline & $\begin{array}{l}\text { Bağımsız Okul } \\
\text { Müdürlüğü }\end{array}$ & 39 & 19.8 \\
\hline & Diğer Yöneticilikler & 48 & 24.3 \\
\hline \multirow{5}{*}{$\begin{array}{l}\text { Birlikte çalışılan } \\
\text { müfettiş sayısı }\end{array}$} & 1) 10 ve daha az & 19 & 9.7 \\
\hline & 2) $11-20$ & 17 & 8.6 \\
\hline & 3) $21-30$ & 15 & 7.6 \\
\hline & 4) $31-40$ & 29 & 14.7 \\
\hline & 5) 41 ve üstü & 117 & 59.4 \\
\hline \multirow{4}{*}{$\begin{array}{l}\text { Aynı ilde görev yapma } \\
\text { süresi }\end{array}$} & 3 y1l ve az & 36 & 18.3 \\
\hline & $4-6$ yıl & 104 & 52.8 \\
\hline & $7-9$ y1l & 32 & 16.2 \\
\hline & 10 yıl ve üstü & 25 & 12.7 \\
\hline TOPLAM & & 197 & 100 \\
\hline
\end{tabular}

Tablo 1'in incelenmesinden de anlaşlacağ 1 üzere, araştırmaya katılan 197 ilköğretim müfettişinin 14'ü (\% 7.1) kadın; 183'ü ise (\% 92.9) erkektir. Ayrıca \% 84.8'inin, öğretmenlikteki branşının sınıf öğretmenliği, \% 15.2 'sinin de alan öğretmenliği olduğu görülmektedir. Aynı tabloya göre müfettişlerden \% 55.8'i 31-40 yaşları arasında, \% 33'ü 41-50 yaşları arasında, \%11.2'si ise 50 yaşın üstündedir. Müfettişlerden \% 44.2'sinin önceki çalışma hayatlarında yöneticilik yapmadığ 1 , \% 11.7'sinin okulda müdür yardımcılığı, \% 19.8'inin bağımsız okul müdürlüğü, \% 24.3'ünün ise eğitim sistemi içinde farklı yöneticilikler yaptıkları anlaşılmaktadır. Birlikte çalışılan müfettiş sayısına bakıldığında, 19 (\% 9.7) ilköğretim müfettişinin 10 ve daha az sayıdaki meslektaşla çalıştı̆̆ 1 , 17'sinin (\% 8.6) 11-20 meslektaşla, 15'inin (\% 7.6) 21-30 meslektaşla, 29'unun (\% 14.7) 31-40 meslektaşla, 117'sinin (\% 59.4) ise 41 ve daha fazla müfettişle birlikte çalıştığ 1 görülmektedir. Son olarak müfettişlerden \% 52.8'inin 4-6 y1l süreyle aynı ilde görev yaptıkları, \% 18.3'ünün 3 yıl ve daha az, \% 16.2'sinin 7-9 
yıl, \% 12.7'sinin ise 10 yıl ve daha fazla süreyle aynı ilde görev yaptıkları görülmektedir. Müfettişlerin MTE'den aldıkları puanların ortalama ve standart sapma değerleri Tablo 2'de verilmiştir.

Tablo 2. İlköğretim Müfettişlerinin MTE'den Aldıkları Puanların Ortalama ve Standart Sapma Değerleri

\begin{tabular}{|c|c|c|c|}
\hline Boyut & $\mathbf{N}$ & $\overline{\mathbf{X}}$ & $\mathbf{S}$ \\
\hline Duygusal Tükenme Boyutu & \multirow{3}{*}{197} & 1.72 & 0.73 \\
\hline Duyarsızlaşma Boyutu & & 1.04 & 0.72 \\
\hline Kişisel Başarı Boyutu & & 2.68 & 0.57 \\
\hline
\end{tabular}

Tablo 2'deki ortalamalar ile MTE'nin grafiksel puanlamas1 birlikte dikkate alındığında müfettişlerin tükenmişliğinin, duygusal tükenme boyutunda ikinci üçte birlik sekme içinde yer aldığ $(\bar{X}=1.72)$, duyarsızlaşma boyutunda birinci üçte birlik sekme içinde olduğu, ( $X=1.04$ ), kişisel başarı boyutunda ise ikinci üçte birlik ile üçüncü üçte birlik sekmeler arasında sinırda $(\bar{X}=2.68)$ yer aldığ bulgulardan hareketle, araştırmaya katılan ilköğretim müfettişlerinin tükenmişlik duygularının duygusal tükenme boyutunda orta düzeyde, duyarsızlaşma boyutunda düşük düzeyde, kişisel başarı boyutunda ise sınırda olduğu söylenebilir.

\section{İlköğretim Müfettişlerinin Tükenmişlik Duygularına İlişsin Bulgular}

Araştırmaya katılan ilköğretim müfettişlerinin tükenmişlik duygularına ilişkin bulgular çeşitli değişkenler açısından analiz edilerek tablolar halinde verilmektedir. 
Tablo 3. İlköğretim Müfettişlerinin Tükenmişlik Duygularının Cinsiyet ve Öğretmenlikteki Branş Değişkenlerine Göre T-Testi Sonuçları

\begin{tabular}{|c|c|c|c|c|c|c|c|c|}
\hline Boyut & Değişkenler & Düzey & $\mathbf{N}$ & $X$ & $\mathbf{S}$ & sd & $\mathbf{T}$ & $\mathbf{P}$ \\
\hline \multirow{4}{*}{$\begin{array}{l}\text { Duygusal } \\
\text { Tükenme }\end{array}$} & \multirow[t]{2}{*}{ Cinsiyet } & Erkek & 183 & 1.68 & 0.72 & \multirow[t]{2}{*}{195} & \multirow[t]{2}{*}{2.74} & \multirow[t]{2}{*}{0.00} \\
\hline & & Kadın & 14 & 2.23 & 0.65 & & & \\
\hline & \multirow[b]{2}{*}{$\begin{array}{l}\text { Öğretmenlikteki } \\
\text { Branș }\end{array}$} & Sınıf Öğretmeni & 167 & 1.76 & 0.71 & \multirow[t]{2}{*}{195} & \multirow[t]{2}{*}{2.05} & \multirow[t]{2}{*}{0.04} \\
\hline & & Alan Öğretmeni & 30 & 1.46 & 0.80 & & & \\
\hline \multirow{4}{*}{ Duyarsızlaşma } & \multirow[t]{2}{*}{ Cinsiyet } & Erkek & 183 & 1.02 & 0.72 & \multirow[t]{2}{*}{195} & \multirow[t]{2}{*}{1.03} & \multirow[t]{2}{*}{0.30} \\
\hline & & Kadın & 14 & 1.22 & 0.72 & & & \\
\hline & \multirow{2}{*}{$\begin{array}{l}\text { Öğretmenlikteki } \\
\text { Branş }\end{array}$} & Sınıf Öğretmeni & 167 & 1.03 & 1.71 & \multirow[t]{2}{*}{195} & \multirow[t]{2}{*}{0.08} & \multirow[t]{2}{*}{0.93} \\
\hline & & Alan Öğretmeni & 30 & 1.02 & 0.75 & & & \\
\hline \multirow{4}{*}{ Kişisel Başarı } & \multirow[t]{2}{*}{ Cinsiyet } & Erkek & 183 & 2.70 & 0.57 & \multirow[t]{2}{*}{195} & \multirow[t]{2}{*}{1.21} & \multirow[t]{2}{*}{0.22} \\
\hline & & Kadın & 14 & 2.51 & 0.45 & & & \\
\hline & \multirow{2}{*}{$\begin{array}{l}\text { Öğretmenlikteki } \\
\text { Branș }\end{array}$} & Sınıf Öğretmeni & 167 & 2.69 & 0.55 & \multirow[t]{2}{*}{195} & \multirow[t]{2}{*}{0.12} & \multirow[t]{2}{*}{0.89} \\
\hline & & Alan Öğretmeni & 30 & 2.67 & 0.65 & & & \\
\hline
\end{tabular}

$\mathrm{P}<0.05$

Tablo 3'e göre araştırmaya katılan müfettişlerin tükenmişlik duyguları onların cinsiyetlerine göre duygusal tükenme boyutunda $\left[\mathrm{t}_{(195)=} 2.74\right.$; $\left.\mathrm{P}<0.05\right]$

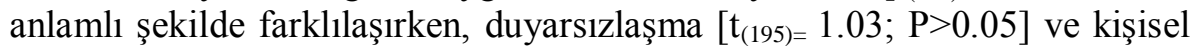

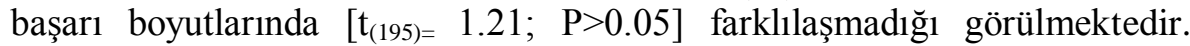
Bulgulara göre duygusal tükenme boyutunda, kadın ilköğretim müfettişlerinin ( $\bar{X}=2.23$ ) tükenmişlikleri, erkek meslektaşlarına göre ( $\bar{X}=1.68$ ) daha yüksek düzeyde bulunmuştur.

Aynı tabloya göre araştırmaya katılan ilköğretim müfettişlerinin tükenmişlik duyguları onların öğretmenlikteki branşlarına göre duygusal tükenme boyutunda $\left[\mathrm{t}_{(195)}=2.05 ; \mathrm{p}<0.05\right]$ anlaml ş̧ekilde farklılaşırken, duyarsızlaşma $\left[\mathrm{t}_{(195)=} 0.08 ; \mathrm{P}>0.05\right]$ ve kişisel başarı boyutlarında $\left[\mathrm{t}_{(195)=} 0.12\right.$; $\mathrm{P}>0.05$ ] farklılaşmadığ 1 görülmektedir. Bulgulara göre duygusal tükenme boyutunda, sınıf öğretmenliği yapmış ilköğretim müfettişlerinin $(\bar{X}=1.76)$ tükenmişlikleri, alan öğretmenliği yapmış olanlara göre $(\bar{X}=1.46)$ daha yüksek bulunmuştur.

Araştırmaya katılan müfettişlerin tükenmişlik duygularının yaş ve müfettişlikten önce yöneticilik görevinde bulunup bulunmama değişkenlerine göre varyans analizi sonuçları Tablo 4'de verilmektedir. 
Tablo 4. İlköğretim Müfettişlerinin Tükenmişlik Duygularının Yaş ve Müfettişlikten Önce Yöneticilik Görevinde Bulunma Değişkenlerine Göre Varyans

Analizi Sonuçları

\begin{tabular}{|c|c|c|c|c|c|c|c|c|c|}
\hline Boyut & Değişken & Düzey & $\mathbf{N}$ & $\bar{X}$ & $\mathbf{S}$ & sd & $\mathbf{F}$ & $\mathbf{P}$ & $\begin{array}{l}\text { Gruplar } \\
\text { arası Fark }\end{array}$ \\
\hline \multirow{8}{*}{$\begin{array}{l}\text { Duygusal } \\
\text { Tükenme }\end{array}$} & & 1) $31-40$ & 110 & 1.90 & 0.68 & $2 ; 194$ & 12.56 & 0.00 & $1-2$ \\
\hline & Yaş & 2) $41-50$ & 65 & 1.61 & 0.70 & & & & $1-3$ \\
\hline & & 3) 51 ve üstü & 22 & 1.12 & 0.71 & & & & \\
\hline & \multirow{5}{*}{$\begin{array}{l}\text { Müfettişlikten Önce } \\
\text { Yöneticilik } \\
\text { Görevinde } \\
\text { Bulunma }\end{array}$} & 1) Yöneticilik Yapmayan & 87 & 1.91 & 0.71 & \multirow[t]{5}{*}{$3 ; 193$} & \multirow[t]{5}{*}{4.15} & \multirow[t]{5}{*}{0.00} & \multirow{5}{*}{$\begin{array}{l}1-3 \\
1-4\end{array}$} \\
\hline & & 2) $\quad$ Okulda $\quad$ Müdür & 23 & 1.65 & 0.91 & & & & \\
\hline & & Yardımcılığı & & & & & & & \\
\hline & & 3) Bağımsız Okul Müdürlüğü & 39 & 1.56 & 0.63 & & & & \\
\hline & & 4) Diğer Yöneticilikler & 48 & 1.52 & 0.66 & & & & \\
\hline \multirow{7}{*}{ Duyarsızlaşma } & \multirow{3}{*}{ Yaş } & 1) $31-40$ & 110 & 1.16 & 0.72 & \multirow{3}{*}{$2 ; 194$} & \multirow{3}{*}{5.46} & \multirow{3}{*}{0.00} & \multirow{3}{*}{$1-3$} \\
\hline & & 2) $41-50$ & 65 & 0.96 & 0.71 & & & & \\
\hline & & 3) 51 ve üstü & 22 & 0.64 & 0.53 & & & & \\
\hline & \multirow{4}{*}{$\begin{array}{l}\text { Müfettişlikten Önce } \\
\text { Yöneticilik } \\
\text { Görevinde } \\
\text { Bulunma }\end{array}$} & 1) Yöneticilik Yapmayan & 87 & 1.18 & 0.74 & \multirow{4}{*}{$3 ; 193$} & \multirow{4}{*}{4.50} & \multirow{4}{*}{0.00} & \multirow{4}{*}{$1-4$} \\
\hline & & 2)Okulda Müdür Yardımcılığı & 23 & 1.15 & 0.93 & & & & \\
\hline & & 3) Bağımsız Okul Müdürlüğü & 39 & 1.01 & 0.56 & & & & \\
\hline & & 4) Diğer Yöneticilikler & 48 & 0.73 & 0.58 & & & & \\
\hline \multirow{7}{*}{ Kişisel Başarı } & \multirow[t]{3}{*}{ Yaş } & 1) $31-40$ & 110 & 2.59 & 0.52 & \multirow{3}{*}{$2 ; 194$} & \multirow{3}{*}{4.12} & \multirow{3}{*}{0.01} & \multirow{3}{*}{$1-3$} \\
\hline & & 2) $41-50$ & 65 & 2.77 & 0.59 & & & & \\
\hline & & 3) 51 ve üstü & 22 & 2.91 & 0.64 & & & & \\
\hline & \multirow{4}{*}{$\begin{array}{l}\text { Müfettişlikten Önce } \\
\text { Yöneticilik } \\
\text { Görevinde } \\
\text { Bulunma }\end{array}$} & 1) Yöneticilik Yapmayan & 87 & 2.48 & 0.56 & \multirow{4}{*}{$3 ; 193$} & \multirow{4}{*}{11.39} & \multirow{4}{*}{0.00} & \multirow{4}{*}{$\begin{array}{l}1-4 \\
3-4\end{array}$} \\
\hline & & 2)Okulda Müdür Yardımcılığı & 23 & 2.72 & 0.61 & & & & \\
\hline & & 3) Bağımsız Okul Müdürlüğü & 39 & 2.70 & 0.46 & & & & \\
\hline & & 4) Diğer Yöneticilikler & 48 & 3.03 & 0.45 & & & & \\
\hline
\end{tabular}


Tablo 4'de görüldüğg̈ gibi araştırmaya katılan ilköğretim müfettişlerinin tükenmişlik duyguları onların yaşlarına göre duygusal tükenme $\left[\mathrm{F}_{(2-194)}=\right.$ $12.56 ; \mathrm{P}<0.05]$, duyarsızlaşma $\left[\mathrm{F}_{(2-194)}=5.46 ; \mathrm{P}<0.05\right]$ ve kişisel başarı $\left[\mathrm{F}_{(2-}\right.$ $\left.{ }_{194)}=4.12 ; \mathrm{P}<0.05\right]$ boyutlarında anlamlı şekilde farklılaşmaktadır. Aynı tabloya göre katılımcıların tükenmiş̧lik duyguları onların müfettişlikten önce yöneticilik görevinde bulunup bulunmamalarına göre duygusal tükenme $\left[\mathrm{F}_{(3-}\right.$ $\left.{ }_{193)}=4.15 ; \mathrm{P}<0.05\right]$, duyarsızlaşma $\left[\mathrm{F}_{(3-193)}=4.50 ; \mathrm{P}<0.05\right]$ ve kişisel başarı $\left[\mathrm{F}_{(3-193)}=11.39 ; \quad \mathrm{P}<0.05\right]$ boyutlarında anlamlı şekilde farkl111k göstermektedir.

Farkların hangi gruplar arasında olduğu Scheffe ve Dunnet C testleri ile incelenmiştir. Bulgulara göre, duygusal tükenme boyutunda 31-40 yaşları arasında olan müfettişlerin tükenmişlik duyguları $(\bar{X}=1.90)$, hem 41-50 yaşları arasında olan ilköğretim müfettişlerinden $(\bar{X}=1.61)$, hem de 51 ve üstü yaşlarda olan müfettişlerden $(\bar{X}=1.12)$ daha yüksek bulunmuştur. Ayrıca 41-50 yaşları arasında bulunan ilköğretim müfettişlerinin bu boyuttaki tükenmişlik düzeyleri ( $\bar{X}=1.61$ ), 51 ve üstü yaşlarda bulunan ilköğretim müfettişlerine $(\bar{X}=1.12)$ göre daha yüksek bulunmuştur. Aynı tabloya göre, duyarsızlaşma boyutunda 31-40 yaşları arasında olan müfettişler ( $\bar{X}=1.16), 51$ ve üstü yaşlarda olan müfettişlerden $(\bar{X}=0.64)$ daha fazla tükenmişlik yaşarken, 51 ve üstü yaşlarda olan müfettişlerin kişisel başarı algıları ( $\bar{X}=2.91), 31-40$ yaşları arasındaki müfettişlerden ( $\bar{X}=2.59$ ) daha yüksek çıkmıştır.

Diğer yandan duygusal tükenme boyutunda, müfettişlikten önceki çalışma hayatında yöneticilik görevi yapmamış ilköğretim müfettişlerinin tükenmişlikleri $(\bar{X}=1.91)$, bağımsız okul müdürlüğü yapmış olan müfettişler $(\bar{X}=1.56)$ ve diğer yöneticilik görevi yapmış olanlardan ( $\bar{X}=1.52$ ) daha yüksek bulunurken; duyarsızlaşma boyutunda daha önce yöneticilik görevi yapmamış ilköğretim müfettişlerinin tükenmişlikleri ( $\bar{X}=1.18)$, diğer yöneticilik görevi yapmış meslektaşlarından $(\bar{X}=0.73)$ daha yüksek bulunmuştur. Bulgulara göre ayrıca kişisel başarı boyutunda, müfettişlikten önceki çalışma hayatında diğer yöneticilik görevi yapmış ilköğretim müfettişlerinin kişisel başarı duyguları $(\bar{X}=3.03)$, daha önce yöneticilik görevi yapmamış ( $\bar{X}=2.48$ ) ve bağımsız okul müdürlüğü yapmış olanlardan ( $\bar{X}=2.70$ ) anlamlı şekilde daha yüksek bulunmuştur. 
Araştırmaya katılan ilköğretim müfettişlerinin birlikte çalışılan müfettiş sayısı ve aynı ilde görev yapma sürelerine göre varyans analizi sonuçları Tablo 5'de verilmektedir.

Tablo 5. İlköğretim Müfettişlerinin Tükenmişlik Duygularının Birlikte Çalışılan Müfettiş Sayısı ve Aynı İlde Görev Yapma Değişkenlerine Göre Varyans Analizi Sonuçları

\begin{tabular}{|c|c|c|c|c|c|c|c|c|c|}
\hline Boyut & Değişken & $\overline{\text { Düzey }}$ & $\mathbf{N}$ & $\bar{X}$ & $\mathbf{S}$ & sd & $\mathbf{F}$ & $\mathbf{P}$ & $\begin{array}{l}\text { Gruplar } \\
\text { arası } \\
\text { Fark }\end{array}$ \\
\hline \multirow{9}{*}{$\begin{array}{l}\text { Duygusal } \\
\text { Tükenme }\end{array}$} & \multirow{5}{*}{$\begin{array}{l}\text { Birlikte } \\
\text { Çalışılan } \\
\text { Müfettiş } \\
\text { Sayısı }\end{array}$} & 1) 10 ve az & 19 & 1.72 & 0.62 & \multirow[t]{5}{*}{$4 ; 192$} & \multirow[t]{5}{*}{3.96} & \multirow[t]{5}{*}{0.00} & \multirow[t]{5}{*}{$3-5$} \\
\hline & & 2) $11-20$ & 17 & 1.74 & 0.59 & & & & \\
\hline & & 3) $21-30$ & 15 & 1.20 & 0.56 & & & & \\
\hline & & 4) $31-40$ & 29 & 1.45 & 0.70 & & & & \\
\hline & & $\begin{array}{l}\text { 5) } 41 \text { ve } \\
\text { üstü }\end{array}$ & 117 & 1.84 & 0.75 & & & & \\
\hline & \multirow{4}{*}{$\begin{array}{l}\text { Aynı } \\
\text { İde } \\
\text { Görev } \\
\text { Yapma } \\
\text { Süresi }\end{array}$} & $\begin{array}{l}\text { 1) } 3 \text { Y1l ve } \\
\text { az }\end{array}$ & 36 & 1.64 & 0.71 & \multirow[t]{4}{*}{$3 ; 193$} & \multirow[t]{4}{*}{4.02} & \multirow[t]{4}{*}{0.00} & \multirow[t]{4}{*}{$2-4$} \\
\hline & & 2) 4-6 Y1l & 104 & 1.82 & 0.69 & & & & \\
\hline & & 3) 7-9 Y1l & 32 & 1.80 & 0.79 & & & & \\
\hline & & $\begin{array}{l}\text { 4) } 10 \text { Y11 } \\
\text { ve üstü }\end{array}$ & 25 & 1.29 & 0.71 & & & & \\
\hline \multirow{9}{*}{ Duyarsızlaşma } & \multirow{5}{*}{$\begin{array}{l}\text { Birlikte } \\
\text { Çalışılan } \\
\text { Müfettiş } \\
\text { Sayısı }\end{array}$} & 1) 10 ve az & 19 & 1.11 & 0.62 & \multirow{5}{*}{$4 ; 192$} & \multirow{5}{*}{0.79} & \multirow{5}{*}{0.53} & \multirow{5}{*}{ - } \\
\hline & & 2) $11-20$ & 17 & 0.91 & 0.60 & & & & \\
\hline & & 3) $21-30$ & 15 & 0.77 & 0.62 & & & & \\
\hline & & 4) $31-40$ & 29 & 1.12 & 0.75 & & & & \\
\hline & & $\begin{array}{l}\text { 5) } 41 \text { ve } \\
\text { üstü }\end{array}$ & 117 & 1.05 & 0.75 & & & & \\
\hline & \multirow{4}{*}{$\begin{array}{l}\text { Aynı } \\
\text { İlde } \\
\text { Görev } \\
\text { Yapma } \\
\text { Süresi }\end{array}$} & $\begin{array}{l}\text { 1) } 3 \text { Yil ve } \\
\text { az }\end{array}$ & 36 & 0.90 & 0.73 & \multirow{4}{*}{$3 ; 193$} & \multirow{4}{*}{1.86} & \multirow{4}{*}{0.13} & \multirow{4}{*}{ - } \\
\hline & & 2) 4-6 Y1l & 104 & 1.05 & 0.67 & & & & \\
\hline & & 3) 7-9 Y1l & 32 & 1.25 & 0.82 & & & & \\
\hline & & $\begin{array}{l}\text { 4) } 10 \text { Y1l } \\
\text { ve üstü }\end{array}$ & 25 & 0.86 & 0.68 & & & & \\
\hline \multirow[t]{9}{*}{ Kişisel Başarı } & \multirow{5}{*}{$\begin{array}{l}\text { Birlikte } \\
\text { Çalışılan } \\
\text { Müfettiş } \\
\text { Sayısı }\end{array}$} & 1) 10 ve az & 19 & 2.47 & 0.45 & \multirow{5}{*}{$4 ; 192$} & \multirow{5}{*}{1.28} & \multirow{5}{*}{0.27} & \multirow{5}{*}{ - } \\
\hline & & 2) $11-20$ & 17 & 2.79 & 0.40 & & & & \\
\hline & & 3) $21-30$ & 15 & 2.88 & 0.51 & & & & \\
\hline & & 4) $31-40$ & 29 & 2.66 & 0.67 & & & & \\
\hline & & $\begin{array}{l}\text { 5) } 41 \mathrm{ve} \\
\text { üstü }\end{array}$ & 117 & 2.68 & 0.58 & & & & \\
\hline & \multirow{4}{*}{$\begin{array}{l}\text { Aynı } \\
\text { İlde } \\
\text { Görev } \\
\text { Yapma } \\
\text { Süresi }\end{array}$} & $\begin{array}{l}\text { 1) } 3 \text { Yil ve } \\
\text { az }\end{array}$ & 36 & 2.86 & 0.57 & \multirow{4}{*}{$3 ; 193$} & & & \\
\hline & & 2) 4-6 Y1l & 104 & 2.60 & 0.48 & & & & \\
\hline & & 3) 7-9 Y1l & 32 & 2.62 & 0.63 & & 2.96 & 0.06 & - \\
\hline & & $\begin{array}{l}\text { 4) } 10 \text { Yıll } \\
\text { ve üstü }\end{array}$ & 25 & 2.86 & 0.72 & & & & \\
\hline
\end{tabular}

Tablo 5'de görüldüğü gibi ilköğretim müfettişlerinin tükenmişlik duyguları birlikte çalışılan müfettiş sayısına göre duygusal tükenme boyutunda $\left[\mathrm{F}_{(4-192)}=3.96 ; \quad \mathrm{P}<0.05\right]$ anlamlı şekilde farklılaşırken, duyarsızlaşma $\left[\mathrm{F}_{(4-192)}=0.79 ; \mathrm{P}>0.05\right]$ ve kişisel başarı $\left[\mathrm{F}_{(4-192)}=1.28\right.$; $\mathrm{P}>0.05$ ] boyutlarında anlamlı şekilde farklılık göstermediği görülmektedir. 
Bulgulara göre katılımcıların tükenmişlik duyguları, onların aynı ilde görev yapma sürelerine göre duygusal tükenme boyutunda $\left[\mathrm{F}_{(3-193)}=4.02 ; \mathrm{P}<0.05\right]$ anlamlı şekilde farkl11ık gösterirken, duyarsızlaşma $\left[\mathrm{F}_{(3-193)}=1.86 ; \mathrm{P}>0.05\right]$ ve kişisel başarı $\left[\mathrm{F}_{(3-193)}=2.96 ; \mathrm{P}>0.05\right]$ boyutlarında anlamlı şekilde farklılaşmadığ bulunmuştur.

Farkların hangi gruplar arasında olduğu Scheffe ve Dunnett $\mathrm{C}$ testleri ile incelenmiştir. Buna göre birlikte çalışılan müfettiş sayısına göre, 41 ve daha fazla müfettişle çalışan müfettişlerin tükenmişlik düzeyleri $(\bar{X}=1.84)$, 21-30 arası müfettişle çalışanlardan $(\bar{X}=1.20)$ daha yüksek bulunmuştur. Bulgular ayrıca, aynı ilde görev yapma sürelerine göre 4-6 yıl arası süreyle aynı ilde çalışan ilköğretim müfettişlerinin tükenmişlik düzeylerinin $(\bar{X}=1.82), 10$ yıl ve daha fazla süreyle aynı ilde çalışanlardan $(\bar{X}=1.29)$ anlamlı şekilde daha yüksek olduğunu ortaya koymuştur.

\section{Tartışma}

GAP bölgesinde görev yapan ilköğretim müfettişlerinin tükenmişlik duygularının hangi düzeyde olduğunu çeşitli değişkenler açısından incelemeyi amaçlayan bu araştırma, müfettişlerin tükenmişlik duygularının duygusal tükenme boyutunda orta düzeyde, duyarsızlaşma boyutunda düşük düzeyde, kişisel başarı boyutunda ise sınırda olduğunu ortaya koymuştur.

Sonuçlara göre duygusal tükenme boyutunda, kadın ilköğretim müfettişlerinin tükenmişlikleri, erkek meslektaşlarına göre daha yüksek düzeyde ortaya çıkmıştır. Literatürde cinsiyetin duygusal tükenmeyi etkilemediğini gösteren araştırmalara (Izgar, 2001) karşın, bu araştırmadaki bulgular, Shapiro (1987), Baysal (1995) ve S1lı̆̆'ın (2003) araştırma sonuçlarını destekleyici sonuçlar ortaya koymuştur. Shapiro (1987) ve Baysal'ın (1995) öğretmenlerin tükenmişlik düzeyleriyle ilgili yaptıkları araştırma sonuçları ile Sılığ'ın (2003) banka çalışanlarının tükenmişlik düzeyleriyle ilgili yaptığı araştırma sonuçları da kadın işgörenlerin erkek meslektaşlarına göre daha yüksek düzeyde tükendiklerini ortaya koymuştur. $\mathrm{Bu}$ araştırmada kadın ilköğretim müfettişlerinin, doğalarından gelen duygusal özellikleri, fiziksel olarak daha az dayanıklı olmaları ve insan ilişkilerine daha fazla önem verme eğilimlerinin, mesleklerini yaparken duygusal tükenmişliği daha yoğun yaşamalarında etken olduğu söylenebilir.

Diğer yandan, bu araştırmanın sonuçlarına göre duygusal tükenme boyutunda, sınıf öğretmenliği yapmış ilköğretim müfettişlerinin tükenmişlikleri, alan öğretmenliği yapmış olanlardan anlamlı şekilde daha yüksek bulunmuştur. Müfettişlikten önceki çalışma yaşamlarında sınıf öğretmenliği yapan ilköğretim müfettişlerinin duygusal tükenme 
düzeylerinin branş öğretmenliği yapanlardan anlamlı şekilde daha yüksek çıkması, sınıf ögretmenliğinde yaşça daha küçük öğrencilerle daha uzun zaman geçirilmesi nedeniyle duygusallı̆̆ın arttı̆̆ı, ayrıca alan öğretmenliğinden gelen müfettişlerin sayısının az olması nedeniyle (\% 15.2), sınıf öğretmenliğinden gelen müfettişlerin branş öğretmenliğinden gelen müfettişlere rehberlik yaparken zorlandıkları ve bunun tükenmişliklerini arttırdığı şeklinde yorumlanabilir. Bu sonuçlara karşın, Izgar (2001) tarafından yapılan araştırmada okul yöneticilerinin tükenmişlik düzeyi ile branşları arasında duygusal tükenme boyutunda anlamlı ilişki bulunmuş, meslek dersi branşından olan yöneticilerin duygusal tükenmişlik düzeylerinin diğerlerinden daha yüksek olduğu bulunmuştur. Gencer'in (2002) öğretmenler üzerinde yapmış olduğu araştırmada ise, bu araştırma sonuçlarından farklı olarak branş öğretmenlerinin tükenmişlik düzeyinin sınıf öğretmenlerinden daha yüksek olduğu bulunmuştur.

Araştırmada, duygusal tükenme ve duyarsızlaşma boyutlarında tükenmişlik ortalamaları genç grupta en yüksek iken, yaş ilerledikçe tükenmişlik ortalamalarının düştüğü ortaya çıkmıştır. Diğer bir deyişle yaş ile tükenmiş̧ik arasında ters bir ilişki vardır. Yaş ilerledikçe duygusal tükenme ve duyarsızlaşma şeklindeki tükenmişlik azalırken, kişisel başarı duygusunda artış olduğu gözlenmektedir. Görevin ilk yıllarında daha idealist olarak göreve başlayarak birçok başarılar elde edeceğini, herkesin kendileriyle işbirliğine gideceğini düşünen ilköğretim müfettişlerinde, tecrübe eksikliğinin, önerilerinin yeterince dikkate alınmamasının ve beklentilerinin tam olarak karşılanmamasının tükenmişlik düzeylerini arttıran etkenler olduğu söylenebilir. Ülkemizde, literatürde yaşın duygusal tükenmeyi etkilemediğini gösteren bulgular yanında (Demir, 1995), etkileyen bir faktör olduğu bazı araştırmalarla ortaya konmuştur (Özmen 2001; Aslan, 2005). Yurt dışında ise, Maslach ve Jackson'ın (1981) yaptığ 1 araştırmada, yaş yükseldikçe tükenmişliğin azaldığ 1 bulunmuştur. Erken yaş gruplarındaki müfettişlerin, daha ileri yaşta olanlara göre daha yüksek düzeyde duygusal tükenme ve duyarsızlaşma, buna karşın daha düşük kişisel başarı duygusu yaşamaları onların genç yaşlardaki yoğun beklentilerine bakılarak da yorumlanabilir. Buna göre, yaşı daha genç olan müfettişlerin, meslekten elde etmeyi umdukları yüksek beklentilerine kavuşamamaları ve karşılaştıkları sorunlarla baş etme yollarında yeterli deneyime sahip olmamalarının tükenmişlik düzeylerini arttıran etkenler olduğu söylenebilir. $\mathrm{Bu}$ araştırmada yaş ve tükenmişlik arasındaki ilişski Ergin (1992), Baysal (1995) ve Izgar'ın (2001) araştırma bulguları ile benzerlik göstermektedir.

Diğer yandan bu araştırma, önceki çalışma hayatında yöneticilik görevi yapmayan grup ile yöneticilik yapan gruplar arasında duygusal tükenme, 
duyarsızlaşma ve kişisel başarı boyutlarında anlamlı fark olduğunu ortaya koymaktadır. Bu bulgu, önceki çalışma hayatında yöneticilik görevi yapmış olmanın, ilköğretim müfettişlerinde tükenmiş̧liği azalttığı, kişisel başarı duygusunu ise arttırdığı şeklinde yorumlanabilir. Bu durumun, yöneticilik görevinin bireysel gelişim ve mesleki deneyim kazandırması, bürokrasi ve kamu kurumlarının işleyişinin daha yakından tanınması ve bu süre içinde sorun çözme becerilerinin gelişmiş olması ile doğrudan ilgili olduğu söylenebilir.

Araştırmanın ortaya koyduğu önemli sonuçlardan biri de ilköğretim müfettişlerinin tükenmişlik duygularının, birlikte çalışılan müfettiş sayısından önemli ölçüde etkilendiği şeklindedir. İlköğretim müfettişlerinin birlikte çalışabilecekleri ideal grubun 21-30 kişiden oluştuğu, daha az sayıda veya daha çok sayıda meslektaş grubuyla çalıştıklarında tükenmişlik duygularının önemli değişim gösterdiği; diğer bir anlatımla, ilköğretim müfettişleri çok kalabalık meslektaş grubuyla çalıştıklarında yalnızlaşmanın etkisiyle, çok az meslektaşla birlikte çalıştıklarında ise iş yüklerinin artması nedeniyle duygusal tükenme düzeylerinin arttığı söylenebilir. Girgin (1995) tarafından yapılan araştırmada da meslektaş desteği gören öğretmenlerde duygusal tükenmiş̧lik düzeyinin düşük olduğu bulunurken, Aydın'ın (2002) ilköğretim okulu yöneticilerinin bireysel tükenmişlik düzeylerinin belirlenmesi amacıyla yaptığı araştırmada, en yüksek duygusal tükenme puanlarının 41-50 arası ögretmenle çalışan yöneticilerde ortaya çıktığı görülmüştür.

Son olarak aynı ilde görev yapma süresinin müfettişlerin tükenmişlik duygularını etkilediği bulunmuştur. En yüksek tükenmişlik düzeyinin 4-6 yıl süreyle aynı ilde çalı̧̧an ilköğretim müfettişlerinde ortaya çıkması, göreve yeni başlayan müfettişlerin ildeki eğitim topluluğu içinde yeterince tanınmadığ 1 , teftiş, inceleme ve soruşturma gibi yorucu ve yıpratıcı sayılabilecek görevleri mesleğin ilk yıllarında yapmaya başlamaları, bu durumun 4-6 yıllık süre sonunda onlardaki yıpranmışl1k duygusunu arttırdığg şeklinde yorumlanabilir. Diğer yandan, 10 yıl ve üstünde süre ile aynı ilde görev yapan ilköğretim müfettişlerinde tükenmişlik düzeyinin en düşük düzeyde görülmesi, bu gruptaki müfettişlerin çalıştıkları ilde bulunmaktan memnun oldukları, başka illere tayinleri çıkabilecek şartlara sahipken kendi istekleriyle bu illerde kalarak görev yapmaya devam ettikleri, daha düşük düzeydeki tükenmişlik duygularının da bundan kaynaklandığı şeklinde yorumlanabilir. 


\section{Öneriler}

- Araştırmada ilköğretim müfettişlerinin tükenmişlik duygusunu orta düzeyde yaşadıkları bulunmuştur. Özellikle tükenmişlik düzeyleri yüksek olan genç ilköğretim müfettişleri, ilk yıllarındaki gayretli çalışmalarından sonra mesleki olarak tükenmeye başladıklarından, ilköğretim müfettiş yardımcılarının, mesleğe ilk girişlerinde yetiştirilmeleri amacıyla verilen hizmet içi eğitim kursunda tükenmişlik kavramı ve tükenmişlikle mücadele etme yolları üzerinde durulmalıdır.

- İlköğretim müfettişlerinin büyük çoğunluğunu, duygusal tükenmeleri yüksek olan sınıf öğretmenliği kökenli müfettişler oluşturmaktadır. Yeni müfettiş alımlarıyla farklı branşlardan ilköğretim müfettişlerinin sayısı arttırılabilir.

- Müfettişlikten önceki çalışma hayatında yöneticilik görevi yapan ilköğretim müfettişlerinin tükenmişlik düzeyleri anlamlı şekilde düşük çıktığından, 'yöneticilik yapmış olma' ilköğretim müfettişi alımlarında öncelik verilen bir nitelik olabilir.

- Aynı ilde 4-6 y1l süreyle görev yapan ilköğretim müfettişlerinin duygusal tükenmeleri diğer gruplara göre daha yüksek bulunmuştur. Aynı ilde ilk üç yıldan sonra mesleki olarak yıpranmaya başlayan bu gruptaki ilköğretim müfettişlerinin başka illere yer değiştirme isteklerinin karşılandığı bir tayin sistemi oluşturulabilir.

- Sonuçlara göre 21-30 kişilik meslektaş grubuyla çalışan ilköğretim müfettişlerinde tükenmişlik düzeyleri düşmektedir. Müfettiş sayısının daha az veya fazla olduğu illerde iletişim kanallarının açık tutulduğu; yalnızlaşma duygusu, rol belirsizliği ve rol çatışmalarını önlemeye yönelik destekleyici, kişisel ilişkileri geliştirici bir örgüt iklimi yaratılabilir. 


\section{KAYNAKLAR}

Altay, M. (2007). Okul yöneticilerinin mesleki tükenmişlik düzeyleri ile çok boyutlu algılanan sosyal destek düzeyleri arasındaki ilişki. Yayınlanmamış Yüksek Lisans Tezi, Tokat: Gaziosmanpaşa Üniversitesi, Sosyal Bilimler Enstitüsü.

Akçamete, G. Kaner, S. ve Sucuoğlu, B. (2001). Öğretmenlerde tükenmişlik, iş doyumu ve kişilik. Ankara: Nobel Yayın Dağıtım.

Aslan, D. Kiper, N ve Karaağaoğlu, E. (2005). Türkiye'de tabip odalarına kayıtlı olan bir grup hekimde tükenmişlik sendromu ve etkileyen faktörler, Ankara: Türk Tabipleri Birliği Yayınları.

Aydın, M. (1993). Çağdaş eğitim denetimi. Ankara: Pegem Yayınları.

Aydın, L. (2002). İlköğretim okulu yöneticilerinin bireysel tükenmişlik düzeylerinin belirlenmesi. Yayınlanmamış Yüksek Lisans Tezi, Sakarya: Sakarya Üniversitesi Sosyal Bilimler Enstitüsü.

Babaoğlan, E. (2006). İlköğretim okulu yöneticilerinde tükenmişlik. Yayınlanmamış Doktora Tezi, Bolu: İzzet Baysal Üniversitesi, Sosyal Bilimler Enstitüsü.

Balay, R. (2000). Özel ve resmi liselerde yönetici ve öğretmenlerin örgütsel bağlılığı. Yayınlanmamış Doktora Tezi, Ankara: Ankara Üniversitesi Sosyal Bilimler Enstitüsü.

Baltaş, A ve Baltaş, Z. (1997). Stres ve başa çıkma yolları (17. Basım) İstanbul: Remzi Kitabevi.

Baysal, A. (1995). Lise ve dengi okul öğretmenlerinde meslekten tükenmişliğe etki eden faktörler, Yayınlanmamış Doktora Tezi, İzmir: Dokuz Eylül Üniversitesi Sosyal Bilimler Enstitüsü.

Büyüköztürk, Ş. (2003). Sosyal bilimler için veri analizi el kitabı. Ankara: PegemA Yayıncilik.

Çam, O. (1992). Tükenmişlik envanterinin geçerlilik ve güvenirliğinin araştırılması. R. Bayraktar, İ. Dağ (Ed.), Ankara: VII. Ulusal Psikoloji Kongresi Bilimsel Çalışmaları, 155-160.

Çimen, S. (2007). İlköğretim öğretmenlerinin tükenmişlik yaşantıları ve yeterlik algıları. Yayınlanmamış Yüksek Lisans Tezi, Kocaeli: Kocaeli Üniversitesi Sosyal Bilimler Enstitüsü.

Çokluk, Ö. (2003). Örgütlerde tükenmişlik, C. Elma, K. Demir (Ed.), Yönetimde çağdaş yaklaşımlar: Uygulamalar ve sorunlar, Ankara: Anı Yayıncilik, 109-133. 
Daly, S. (1992). Principal burnout in the public schools. Dissertation Abstract International, 53(7), 2177 A.

Demir, A. (1995). Hemşirelerin tükenmişlik düzeyleri, Yayınlanmamış Yüksek Lisans Tezi, Sivas: Cumhuriyet Üniversitesi Sosyal Bilimler Enstitüsü.

Densten, I. (2001). Re-thinking burnout. Journal of Organizational Behaviour, 22(8), 833- 839.

Dursun, S. (2000). Öğretmenlerde tükenmişlik ile yükleme biçimi: Cinsiyet, eğitim düzeyi ve hizmet süresi değişkenleri arasındaki yordayıcı ilişkilerin incelenmesi, Yayınlanmamış Yüksek Lisans Tezi, Trabzon: Karadeniz Teknik Üniversitesi, Sosyal Bilimler Enstitüsü.

Engin, A. (2006). Milli Eğitim Bakanlığ ilköğretim müfettişlerinin tükenmişlik düzeyleri üzerine bir araştırma. Yayınlanmamış Yüksek Lisans Tezi, Şanlıurfa: Harran Üniversitesi, Sosyal Bilimler Enstitüsü.

Ergin, C. (1992). Doktor ve hemşirelerde tükenmişlik ve Maslach Tükenmişlik Ölçeği'nin uyarlanması. R. Bayraktar, İ. Dağ, (Ed.), Ankara: VII. Ulusal Psikoloji Kongresi Bilimsel Çalışmaları, 143154.

Garcia, F. J., Munoz, E. M. \& Ortiz, M. A. (2004). Personality and contextual variables in teacher burnout. Article in Press, www.sciencedirect.com.

Gençer, A. (2002). Öğretmenlerin iş doyumu ile mesleki tükenmişlik düzeyleri arasındaki ilişkiler. Yayınlanmamış Yüksek Lisans Tezi, Eskişehir: Osmangazi Üniversitesi, Sosyal Bilimler Enstitüsü.

Girgin, G. (1995). İlkokul öğretmenlerinde meslekte tükenmişliğin gelişimini etkileyen değişkenlerin analizi ve bir model önerisi: İzmir ili kırsal ve kentsel yöre karşılaştırması. Yayınlanmamış Doktora Tezi, İzmir: Dokuz Eylül Üniversitesi, Sosyal Bilimler Enstitüsü.

Izgar, H. (2001). Okul yöneticilerinde tükenmişlik. Ankara: Nobel Yayın Dağıtım.

Kaptan, S. (1998). Bilimsel araştırma teknikleri ve istatistik yöntemleri. Ankara: Tekışık Web Ofset Tesisleri.

Kayıkçı, K. (2005). Milli Eğitim Bakanlı̆̆ denetmenlerinin denetim alt sisteminin yapısal sorunlarına ilişkin algıları ve iş doyum düzeyleri. Ankara: Tem-Sen Yayınları No:6.

Maslach, C. \& Jackson, S. (1981). The measurement of experienced burnout. Journal of Occupational Behaviour, (2), 99-113. 
Manlove, E. (1992). Multiple predictors of burnout in child care workers. Dissertation Abstracts International, 53 (7), 3388 B.

MEB, 24.03.2005 tarihli İlköğretim Müfettişlerinin Yer Değiştirme İşlemleri yazis1, Ankara.

Örmen, U. (1993). Tükenmişlik duygusu ve yöneticiler üzerinde bir Uygulama. Yayınlanmamış Yüksek Lisans Tezi, İstanbul: Marmara Üniversitesi Sosyal Bilimler Enstitüsü.

Özmen, H. (2001). Görme engelliler okullarında görev yapan öğretmenlerin tükenmişlik düzeyleri. Yayınlanmamış Yüksek Lisans Tezi, Ankara: Gazi Üniversitesi, Eğitim Bilimleri Enstitüsü.

Randall, S. C. (1993). Teacher burnout, depressive symptoms and coping strategies: Their ralationship in two samples of teachers. Dissertation Abstracts International, 55(9), $763 \mathrm{~A}$.

Sucuoğlu, B ve Kuloğlu-Aksaz, N. (1996). Özürlü çocuklarla çalışan öğretmenlerde tükenmişliğin değerlendirilmesi. Türk Psikoloji Dergisi, 10(36),44-60.

Sağlam, A. Ç. (2003). Eğitim örgütlerinde kuramdan uygulamaya güdüleme. Ankara: Sonay Eğitim Yayıncılık.

Shapiro, B. (1987). The relationship of teacher burnout to individual and environmental variables. Dissertation Abstracts International, 48(5), $1157 \mathrm{~A}$.

Sılığ, A. (2003). Banka çalışanlarının tükenmiş̧lik düzeylerinin çeşitli değişkenler açısından incelenmesi. Yayınlanmamış Yüksek Lisans Tezi, Eskişehir: Anadolu Üniversitesi, Eğitim Bilimleri Enstitüsü.

Taymaz, H. (1997). Ë̆itim sisteminde teftiş. Ankara: Takav Matbaası.

Teague, J. B. (1992). The relationship between various coping styles and burnout among nurses. Dissertation Abstracts International, 53(7), $3797 \mathrm{~B}$.

Torun, A. (1995). Tükenmişlik, aile yapısı ve sosyal destek ilişkileri üzerine bir inceleme. Yayınlanmamış Doktora Tezi, İstanbul: Marmara Üniversitesi, Sosyal Bilimler Enstitüsü.

Tümkaya, S. (1996). Öğretmenlerdeki tükenmişlik, görülen psikolojik belirtiler ve başa çıkma davranışları, Yayınlanmamış Doktora Tezi, Adana: Çukurova Üniversitesi,Sosyal Bilimler Enstitüsü.

Üstün, B. (1995). Hemşirelerin atılganlık ve tükenmişlik düzeyleri ve tükenmişliğini etkileyen bazı faktörlerin incelenmesi. Yayınlanmamış Doktora Tezi, Ankara: Hacettepe Üniversitesi, Sosyal Bilimler Enstitüsü. 
Walcott, J. \& Erwin, N. (1992). Stressors in the workplace: Community Health Nurses. Public Health Nurs, 9(1), 66-71.

Walter, H.G. \& Gates, G. (1998). The impact of personal, professional and organizational characteristics on administrator burnout. Journal of Educational Administration, 36(2),146-153.

Yıldırım, F. (1996). Banka çalışanlarının iş doyumu ve algılanan rol çatışması ile tükenmişlik arasındaki ilişki. Yayınlanmamış Yüksek Lisans Tezi, Ankara: Hacettepe Üniversitesi, Sosyal Bilimler Enstitüsü. 